University of Nebraska - Lincoln

DigitalCommons@University of Nebraska - Lincoln

1981

\title{
Influence of Windbreak-shelter on soybean production under rainfed conditions
}

\author{
S.N. Ogbuehi \\ James R. Brandle \\ University of Nebraska - Lincoln, jbrandle1@unl.edu
}

Follow this and additional works at: https://digitalcommons.unl.edu/natrespapers

Part of the Natural Resources and Conservation Commons, Natural Resources Management and Policy Commons, and the Other Environmental Sciences Commons

Ogbuehi, S.N. and Brandle, James R., "Influence of Windbreak-shelter on soybean production under rainfed conditions" (1981). Papers in Natural Resources. 1085.

https://digitalcommons.unl.edu/natrespapers/1085

This Article is brought to you for free and open access by the Natural Resources, School of at DigitalCommons@University of Nebraska - Lincoln. It has been accepted for inclusion in Papers in Natural Resources by an authorized administrator of DigitalCommons@University of Nebraska - Lincoln. 
Reprinted from Agronomy Journal

Vol. 73, July-August 1981, p. 625-628

\title{
Influence of Windbreak-shelter on Soybean Production under Rainfed Conditions ${ }^{1}$
}

\author{
S. N. Ogbuehi and J. R. Brandle ${ }^{2}$
}

\begin{abstract}
Reseanch indicates that a combination of windbreak and irrigation gives significant soybean yield increases in comparison to an irrigated open field. Little data is available to determine the yield advantage of soybean production under sheltered and rainfed conditions. The field study reported here was conducted at the University of Nebraska Field Laboratory, Mead, Nebraska, during 1978 and 1979 growing seasons to determine the influence of windbreak-shelter on soil water content and soybean [Glycine max (L.) Merr.] yield under rainfed conditions. Shelter from wind was provided by a system of east-west oriented shelterbelts, $6 \mathrm{~m}$ high, $60 \%$ dense, and consisting of green ash (Fraxinus pennsylvanica L.), Austrian pine (Pinus nigra Arnold), and eastern red cedar (Juniperus virginiana L.). The prevailing winds in Nebraska during the summer months come mainly from the south. The soil was a Typic Argiudoll.

There were no statistically significant differences ( $P$ $=0.05$ ) between treatments in available soil water and plant water use. In spite of this, sheltered soybeans had higher leaf water potential and stomatal conductance, and lower leaf temperature. These differences between treatments were attributable, entirely, to shelter-induced modification of the growing season microclimate. Leaf area index, dry matter production, and bean yield were significantly increased in shelter during both years. Bean yield in shelter was 20 and $26 \%$ higher than in exposed plots in 1978 and 1979, respectively. Bean production per ha-cm of water used in 1979 was $58 \mathrm{~kg}$ for sheltered soybeans and $47 \mathrm{~kg}$ for those in exposed plots.

Results of this study indicated that under rainfed con. ditions, increased water-use efficiency, and significant increases in bean yield can be expected from sheltered soybeans.
\end{abstract}

Additional index words: Soil water content, Plant water status, Water-use efficiency.

A

VAILABLE soil water is an important factor in crop production $(1,13)$ and the use of windbreaks to conserve this valuable resource is well documented $(5,6,7)$. Plant water status is a function of soil water content and atmospheric evaporative demand, and influences crop growth, development, and yield (14).

${ }^{1}$ Published as Paper No. 6068 Journal Series, Nebraska Agric. Exp. Stn. Received 20 Aug. 1980.

${ }^{2}$ Graduate assistant and assistant professor, Dep. of Forestry, Fisheries and Wildlife, Univ, of Nebraska-Lincoln, NE 68583.
Wind reduction by windbreaks decreases atmospheric evaporative demand and creates a more favorable plant water status $(2,4,11,15)$.

Several reports indicate that soybean [Glycine max (L.) Merr.] respond to the windbreak microclimate with improved plant water status, growth, and yield $(3,8)$. Radke and Hagstrom (9), however, did not observe improved plant water status in soybeans sheltered by temporary corn windbreaks, even though growth and bean yield were increased. Frank et al. (3) reported that a combination of shelter and irrigation resulted in the most favorable soybean plant water status and the highest growth and yield responses. Their results indicated no significant growth and yield responses to shelter under rainfed conditions. Little data is available to determine the yield advantage of soybean production under sheltered and rainfed conditions. The objectives of this study were to determine the effect of windbreak-shelter on soil water content and soybean production under rainfed conditions.

\section{MATERIALS AND METHODS}

'Wayne' soybeans were planted on 19 May during 1978 and 1979 growing seasons under windbreak-sheltered and exposed conditions. Plant rows, $92 \mathrm{~cm}$ apart, were oriented in a northsouth direction. The study was carried out at the University of Nebraska-Lincoln Field Laboratory, Mead, Nebraska (41. $29^{\prime}$ N., $96^{\circ} 30^{\prime}$ W., $354 \mathrm{~m}$ above mean sea level) under dryland field conditions. The soil was a Typic Argiudoll (Sharpsburg silty clay loam). Soil water at one-third and 15 bars was 35 and $16 \%$, respectively. A system of east-west oriented shelterbelts ( $6 \mathrm{~m}$ high and about $60 \%$ dense), established in 1964 for windbreak research, provided shelter from wind. The prevailing winds in Nebraska during the summer months come mainly from the south. Each windbreak consisted of two rows of green ash (Fraxinus pennsylvanica L.), Austrian pine (Pinus nigra Arnold), and estern red cedar (Juniperus virginiana L.). Experimental plots $(9 \mathrm{~m} \times 10 \mathrm{~m})$ were randomly selected within an approximately 1.6 ha bean field. The sheltered plots were located at distances of $1 \mathrm{H}, 2.5 \mathrm{H}, 4 \mathrm{H}$, and $6.5 \mathrm{H}(\mathrm{H}=$ windbreak height) leeward from the windbreaks. The exposed plots were located about $0.5 \mathrm{~km}$ east of the windbreaks, and thus, outside their area of influence. Soil chemical analyses for N, P, $\mathrm{K}$, and $\mathrm{pH}$ were similar for all plots. The layout was a completely randomized design with four replications.

In 1978, soil water content determinations were based on gravimetric soil samples taken to a depth of $50 \mathrm{~cm}$ once a week, starting at the one leaf growth stage. Two soil samples 
were taken from the center of each plot. In 1979, profile soil water determinations were made based on gravimetric samples of the top $30 \mathrm{~cm}$ and neutron attenuation meter (Troxler Model - 1255) data taken to a depth of $150 \mathrm{~cm}$ at $30-\mathrm{cm}$ depth increments. One access tube was located in the center of each plot. Soil water measurements were made at planting time and at the following dates and stages of plant development: 6 June (one leaf stage), 27 June (three leaf stage), 19 July (early flowering), 27 July (commencement of podding), 10 August (pods at upper nodes about $2 \mathrm{~cm}$ long), 23 August (commencement of bean development), and 20 September (pod maturity). The wilting coefficient determined for every $10 . \mathrm{cm}$ depth increment to $150 \cdot \mathrm{cm}$ soil depth was used to calculate the available soil water content. Available soil water in any increment was taken as the water in excess of the wilting coefficient.

Precipitation and windspeed (at $2 \mathrm{~m}$ above the crop) were monitored daily with standard meteorological instruments in stalled at each plot site. Evapotranspiration during 1979 growing season was calculated by adding the precipitation received during a measurement period to the amount of water in the profile at the beginning of that period and subtracting the amount of water in the profile at the end of the measurement period. Experimental plots were level and no runoff could be

Table 1. Mean monthly available soil water and windepeed in sheltered and expased soybean plots during 1978 and 1979 growing seasons.

\begin{tabular}{|c|c|c|c|c|c|}
\hline \multirow[b]{2}{*}{ Year } & \multirow[b]{2}{*}{ Month } & \multicolumn{2}{|c|}{ Available water $†$} & \multicolumn{2}{|c|}{ Avg. 24-hour wind } \\
\hline & & Exposed & Sheltered & Exposed & Sheltered \\
\hline & & \multicolumn{2}{|c|}{$\longrightarrow \mathrm{mm} \longrightarrow$} & \multicolumn{2}{|c|}{$-\mathbf{k m} / \mathbf{h r}$} \\
\hline 1978 & $\begin{array}{l}\text { June } \\
\text { July } \\
\text { Aug. } \\
\text { Avg. }\end{array}$ & $\begin{array}{c}10.3 \mathrm{a} \\
8.1 \mathrm{a} \\
5.2 \mathrm{a} \\
7.8 \mathrm{a}\end{array}$ & $\begin{array}{r}11.5 a \\
8.4 a \\
6.1 a \\
8.6 a\end{array}$ & $\begin{array}{l}-\overline{7.5 \mathrm{a}} \\
7.7 \mathrm{a} \\
7.6 \mathrm{a}\end{array}$ & $\begin{array}{l}3 . \overline{9} \mathrm{~b} \\
3.9 \mathrm{~b} \\
3.9 \mathrm{~b}\end{array}$ \\
\hline 1979 & $\begin{array}{l}\text { June } \\
\text { July } \\
\text { Aug. } \\
\text { Avg. }\end{array}$ & $\begin{array}{l}8.9 \mathrm{a} \\
6.6 \mathrm{a} \\
3.1 \mathrm{a} \\
6.2 \mathrm{a}\end{array}$ & $\begin{array}{r}10.4 \mathrm{a} \\
7.3 \mathrm{a} \\
3.5 \mathrm{a} \\
7.7 \mathrm{a}\end{array}$ & $\begin{array}{r}13.5 \mathrm{a} \\
7.1 \mathrm{a} \\
8.6 \mathrm{a} \\
9.7 \mathrm{a}\end{array}$ & $\begin{array}{l}8.1 \mathrm{~b} \\
3.6 \mathrm{~b} \\
4.9 \mathrm{~b} \\
5.5 \mathrm{~b}\end{array}$ \\
\hline
\end{tabular}

- Means in rows under the arme variable followed by the same letter are not significantly different at the $5 \%$ level using L.S.D.

$\dagger 0$ to $30-\mathrm{cm}$ soil depth. Average of 32 measurements. observed during the growing seasons. Water loss from deep percolation was assumed absent because water in the lowest soll profiles was always below field capacity.

Leaf water potential, stomatal diffusive resistance (R), and leaf temperature were evaluated one day each week at 0800 $1000,1200,1400,1600$, and 1800 hours (solar time). The center leaflet of the uppermost fully expanded trifoliates was used for all measurements. At each sampling period, each of the above measurements was made on four randomly selected leaves in each plot. Leaf water potential was measured with the pressure chamber (12); leaf temperature (of abaxial surface) with copper-constantan thermocouples; and leaf diffusive resistance with Model LI-20S porometer (Lambda Instr. Corp.). Measure. ments of stomatal diffusive resistance were made on both leaf surfaces. Leaf conductance $(1 / \mathbf{R})$ was calculated as follows:

$$
1 / R=1 / \operatorname{Rad}+1 / \mathbf{R a b}
$$

where, Rad and $\mathrm{Rab}$ are adaxial and abaxial leaf diffusive resistance, respectively.

Starting at the two leaf growth stage, estimates of dry matter production and leaf area index were made once a week by cutting plants at ground level from four randomly selected meterlength row segments within each plot. The samples were taken to the laboratory where the leaves were spearated from the stems, Leaf area was measured with Model LI-3000 area meter, and an accessory transparent belt conveyor, Model LI-3050 (Lambda Instr. Corp.). Plant parts were oven-dried to constant weight

Table 2. Available ooil water at different dates during 1979 growing season in sheltered and exposed soybean plots.

\begin{tabular}{lccc}
\hline & \multicolumn{2}{c}{ Available soil water $\dagger$} & \\
\cline { 2 - 3 } Date & Exposed & Sheltered & L.S.D. (0.05) \\
\hline & \multicolumn{3}{c}{$\mathrm{mm}$} \\
19 May & 136.8 & 141.6 & \\
6 June & 152.6 & 158.4 & 6.8 \\
27 June & 154.9 & 162.1 & 13.2 \\
19 July & 99.9 & 113.1 & 15.9 \\
27 July & 82.3 & 86.4 & 11.5 \\
10 Aug. & 82.0 & 85.0 & 8.5 \\
23 Aug. & 70.1 & 70.2 & 16.8 \\
20 Sept. & 65.3 & 68.8 & 6.5 \\
\hline
\end{tabular}

† 0 to $150 \mathrm{~cm}$ depth. Average of 40 measurements.

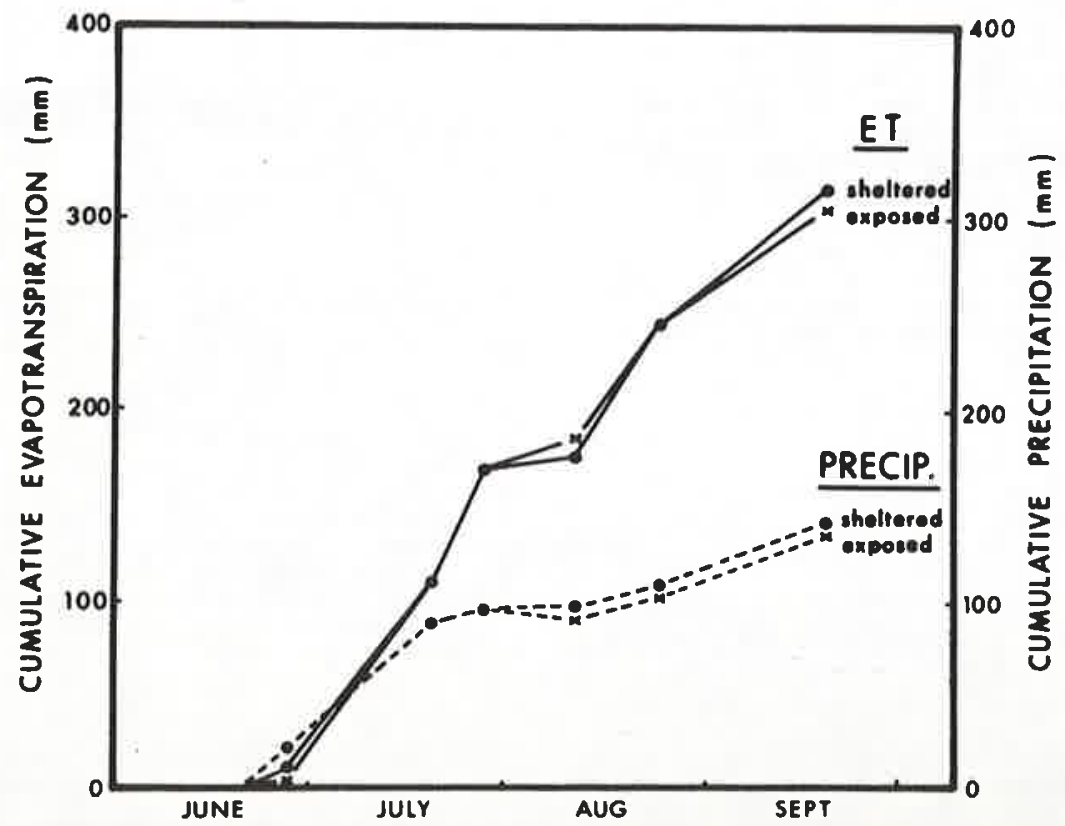

Fig. 1. Cumulative evapotranspiration and precipitation in sheltered and exposed soybean plots during 1979 growing season. 
at $70 \mathrm{C}$. At maturity, bean yield estimations were made on plants clipped from four meter-length row segment randomly selected within each plot.

Because shelter effect varies with distance from windbreak (15), data from the sheltered plots were pooled to average out the effect of location. The pooled data provides a better estimate of the overall windbreak influence on soybean production than data obtained from only one location in shelter.

\section{RESULTS AND DISCUSSION}

The main effect of a windbreak is reduction of surface windspeed in the sheltered zone. This causes changes in the microclimate that have been proven conducive to improved crop growth and yield $(5,15)$. In the study reported here, windspeed was significantly reduced in the sheltered plots (Table 1). The percentage windspeed reduction in shelter averaged 49 and $43 \%$ of the exposed site windspeed during 1978 and 1979 , respectively. There were no significant differences between treatments in available soil water during the study periods (Tables 1 and 2). Even though many researchers have found greater soil water content in sheltered plots (15), this has not always been the case $(3,11)$. Soil water relationships are a function of the factors that enrich the soil with water (snow and precipitation) and those that cause water

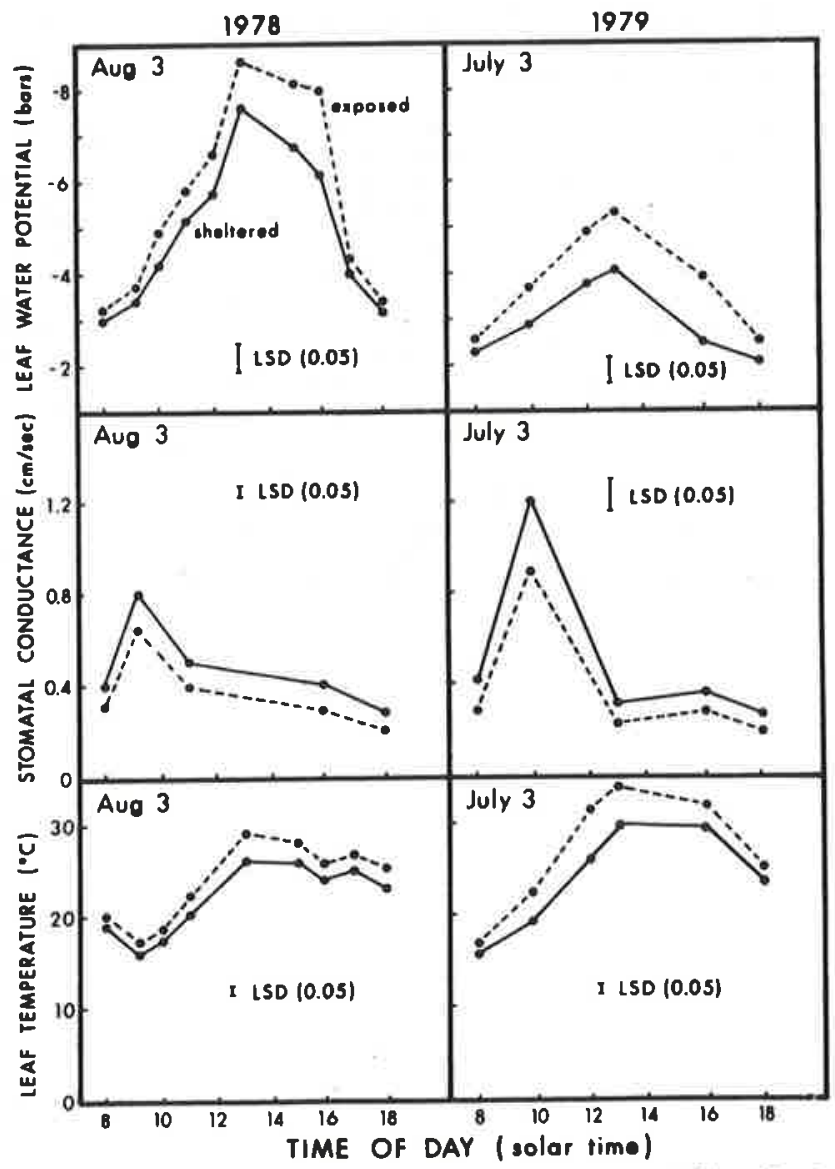

Fig. 2. Diurnal trends of leaf water potential, stomatal conductance, and leaf temperature in sheltered and exposed soybeans on 3 Aug. 1978 and 3 July 1979. loss from the soil (evapotranspiration). Windbreaks influence soil water content in the sheltered zone through efficient snow trapping and distribution over the adjacent field in winter, and reduced evapotranspiration in summer $(5,15)$. At densities of $50 \%$ and less, windbreaks are efficient in trapping snow over a wide cropping area and thus contribute to soil water recharge (4). The density of our windbreak was about $60 \%$ and this would partly explain the absence of any significant differences in available soil water between our sheltered and exposed plots. Large snow drifts ( 1 to $2 \mathrm{~m}$ deep) were observed adjacent to these windbreaks during early spring in 1978 and 1979; an indication of their inefficiency in the distribution of trapped snow over the adjacent land.

Evapotranspiration and precipitation were also the same for both treatments (Fig. 1). For each treatment, evapotranspiration exceeded precipitation during most of the growing season; and differences between these increased as the season progressed. By the end of the study period, net loss of available water from the 0 to $150-\mathrm{cm}$ soil profile amounted to 150 and $145 \mathrm{~mm}$ for sheltered and exposed plots, respectively. This 5$\mathrm{mm}$ difference in water use was not significant $(\mathrm{P}=$ 0.05 ). Radke and Burrows (8) working with temporary corn windbreaks also found no significant differences in water use between their dryland sheltered and exposed soybeans.

Despite the absence of any significant differences between treatments in available soil water; leaf area index, dry matter production, and bean yield were significantly increased in shelter during both years (Tables 3 and 4). This growth and yield advantage of sheltered soybeans was completely attributed to

Table 3. Mean monthly leaf area index and plant dry weight of sheltered and exposed soybeans during 1978 and 1979 growing seasons.

\begin{tabular}{|c|c|c|c|c|c|}
\hline \multirow[b]{2}{*}{ Year } & \multirow[b]{2}{*}{ Month } & \multicolumn{2}{|c|}{ Leaf area index $\dagger$} & \multicolumn{2}{|c|}{ Plant dry matter $\uparrow$} \\
\hline & & Exposed & Sheltered & Exposed & Sheltared \\
\hline & & & & \multicolumn{2}{|c|}{$-\mathrm{g} / \mathrm{m}^{2}-$} \\
\hline 1978 & $\begin{array}{l}\text { June } \\
\text { July } \\
\text { Aug. } \\
\text { Avg. }\end{array}$ & $\begin{array}{l}0.4 \mathrm{a}^{*} \\
2.7 \mathrm{a} \\
4.1 \mathrm{a} \\
2.4 \mathrm{a}\end{array}$ & $\begin{array}{l}0.5 \mathrm{a} \\
3.3 \mathrm{~b} \\
5.8 \mathrm{~b} \\
3.2 \mathrm{~b}\end{array}$ & $\begin{array}{r}20.8 \text { a } \\
214.4 \text { a } \\
543.8 \text { a } \\
259.7 \text { a }\end{array}$ & $\begin{array}{r}24.0 \mathrm{a} \\
251.0 \mathrm{~b} \\
568.3 \mathrm{~b} \\
281.1 \mathrm{~b}\end{array}$ \\
\hline 1979 & $\begin{array}{l}\text { June } \\
\text { July } \\
\text { Aug. } \\
\text { Avg. }\end{array}$ & $\begin{array}{l}0.2 \mathrm{a} \\
1.7 \mathrm{a} \\
3.7 \mathrm{a} \\
1.8 \mathrm{a}\end{array}$ & $\begin{array}{l}0.2 \mathrm{a} \\
2.0 \mathrm{a} \\
4.5 \mathrm{~b} \\
2.2 \mathrm{~b}\end{array}$ & $\begin{array}{r}9.3 \mathrm{a} \\
110.2 \mathrm{a} \\
399.3 \mathrm{a} \\
172.9 \mathrm{a}\end{array}$ & $\begin{array}{r}12.5 \mathrm{a} \\
145.2 \mathrm{~b} \\
445.3 \mathrm{~b} \\
201.0 \mathrm{~b}\end{array}$ \\
\hline
\end{tabular}

- Means in rows under the same variable followed by the same letter are not significantly different at the $5 \%$ level using L.S.D. $\uparrow$ Average of 64 measurements.

Table 4. Soybean yield in sheltered and exposed plots during 1978 and 1979 growing seasons.

\begin{tabular}{ccc}
\hline & \multicolumn{2}{c}{ Bean yield $\dagger$} \\
\cline { 2 - 3 } Year & Exposed & Sheltered \\
\cline { 2 - 3 } 1978 & $1647 \mathrm{a}^{\circ}$ & $1980 \mathrm{~b}$ \\
1979 & $1436 \mathrm{a}$ & $1815 \mathrm{~b}$ \\
\hline
\end{tabular}

- Means in rows followed by the same letter are not significantly different at the $5 \%$ level using L.S.D. † Average of 16 measurements. 
Table 5. Mean monthly leaf water potential $\left(\Psi_{L}\right)$, stomatal conductance $\left(1 / R_{\nu}\right)$, and leaf temperature $\left(T_{\nu}\right)$ at 0800 to 1800 hours, of sheltered and exposed soybeans during 1978 and 1979 growing seasons.

\begin{tabular}{|c|c|c|c|c|c|}
\hline \multirow{2}{*}{$\begin{array}{l}\text { Measure } \\
\text { ment }\end{array}$} & \multirow[b]{2}{*}{ Month } & \multicolumn{2}{|c|}{1978} & \multicolumn{2}{|c|}{1979} \\
\hline & & Exposed & Sheltered & Exposed & Sheltered \\
\hline $\mathbf{T}_{\mathbf{L}}^{\dagger}$ & $\begin{array}{l}\text { June } \\
\text { July } \\
\text { Aug. } \\
\text { Avg. }\end{array}$ & $\begin{array}{l}27.0 \mathrm{a} \\
93.0 \mathrm{a} \\
34.2 \mathrm{a} \\
31.4 \mathrm{a}\end{array}$ & $\begin{array}{l}25.0 \mathrm{a} \\
30.5 \mathrm{~b} \\
30.8 \mathrm{~b} \\
28.8 \mathrm{~b}\end{array}$ & $\begin{array}{l}29.8 \mathrm{a} \\
34.0 \mathrm{a} \\
97.0 \mathrm{a} \\
39.6 \mathrm{a}\end{array}$ & $\begin{array}{l}28.1 \mathrm{a} \\
91.0 \mathrm{~b} \\
33.8 \mathrm{~b} \\
31.0 \mathrm{~b}\end{array}$ \\
\hline${ }_{\text {(bars) }}^{\dagger}$ & $\begin{array}{l}\text { June } \\
\text { July } \\
\text { Aug. } \\
\text { Avg. }\end{array}$ & $\begin{array}{l}-4.5 \mathrm{a} \\
-6.7 \mathrm{a} \\
-8.6 \mathrm{a} \\
-6.2 \mathrm{a}\end{array}$ & $\begin{array}{l}-3.3 \mathrm{~b} \\
-4.2 \mathrm{~b} \\
-6.6 \mathrm{~b} \\
-4.7 \mathrm{~b}\end{array}$ & $\begin{array}{r}-4.8 \mathrm{a} \\
-6.8 \mathrm{a} \\
-10.8 \mathrm{a} \\
-7.6 \mathrm{a}\end{array}$ & $\begin{array}{l}-3.6 \mathrm{a} \\
-5.2 \mathrm{~b} \\
-8.3 \mathrm{~b} \\
-5.7 \mathrm{~b}\end{array}$ \\
\hline$\underset{(\mathbf{c m} / \mathrm{s})}{1 / \mathbf{R}_{\mathbf{L}} \dagger}$ & $\begin{array}{l}\text { June } \\
\text { July } \\
\text { Aug. } \\
\text { Avg. }\end{array}$ & $\begin{array}{l}0.27 \text { a } \\
0.15 \text { a } \\
0.11 \text { a } \\
0.18 a\end{array}$ & $\begin{array}{l}0.50 \mathrm{~b} \\
0.24 \mathrm{~b} \\
0.16 \mathrm{~b} \\
0.30 \mathrm{~b}\end{array}$ & $\begin{array}{l}0.20 \mathrm{a} \\
0.13 \mathrm{a} \\
0.07 \mathrm{a} \\
0.13 \mathrm{a}\end{array}$ & $\begin{array}{l}0.31 \mathrm{~b} \\
0.18 \mathrm{~b} \\
0.19 \mathrm{~b} \\
0.19 \mathrm{~b}\end{array}$ \\
\hline
\end{tabular}

- Means in rowe under 1978 or 1979 followed by the same letter are not significantly different at the $5 \%$ level using L.S.D.

+ Average of 384 measuremente.

greater plant water status, higher stomatal conductance, and lower leaf temperature (Fig. 2 and Table 5). These physiological differences between treatments would be a consequence of the shelter-induced modification of the growing season microclimate (10). Better plant water status in shelter has not always been reflected in crop yield $(5,10)$; nor have improved growth and yield of the sheltered crop always been associated with greater available soil water (9). These findings are testimony of the complexity of the microclimatic interactions in the sheltered zone. Under dryland conditions, sheltered plants could use up more soil water and experience greater water stress than those in exposed plots $(3,11)$.

In the study reported here, shelter increased bean yield above that of the exposed plots by 20 and $26 \%$ in 1978 and 1979, respectively. Frank et al. (3) and Radke and Burrows (8) obtained bean yield increases in dryland sheltered soybeans ranging from 8 to $30 \%$. Bean production per ha-cm of water used in 1979 was 58 and $47 \mathrm{~kg}$ for sheltered and exposed plots, respectively. Windbreaks represent a practical means of increasing the water-use efficiency of crops $(2,8)$. Our results indicated that under rainfed conditions, increased water-use efficiency and significant increases in bean yield can be expected from windbreak-sheltered soybeans.

\section{LITERATURE CITED}

1. Brady, R. A., W. L. Powers, L. R. Stone, and S. M. Goltz. 1974. Relation of soybean leaf water potential to soil water potential. Agron. J. 66:795-798.

2. Brown, K. W., and N. J. Rosenberg. 1972. Shelter effects on microclimate, growth, and water use by irrigated sugar beets in the Great Plains. Agric. Meteorol. 9:241-263.

3. Frank, A. B., D. G. Harris, and W. O. Willis. 1974. Windbreak influence on water relations, growth, and yield of soybeans. Crop Sci. 14:761-765.

4. - $\longrightarrow$, and W. O. Willis. 1978. Effect of winter and summer windbreaks on soil water gain and spring wheat yield. Soil Sci. Soc. Am. J. 42:950-953.

5. Marshall, J. K. 1967. The effect of shelter on the productivity of grasslands and field crops. Field Crop Abstr. 20: $1-14$.

6. Miller, D. R., N. J. Rosenberg, and W. T. Bagley. 1973. Soybean water use in the shelter of a slat-fence windbreak. Agric. Meteorol. 11:405-418.

7. Pelton, N. L. 1967 . The effect of a windbreak on wind travel, evaporation, and wheat yield. Can. J. Plant Sci. 47: 209-214.

8. Radke, J. K., and W. C. Burrows. 1970. Soybean plant response to temporary field windbreak. Agron. J. 62:424. 429.

9. - - and R. T. Hagstrom. 1973. Plant-water measure ments on soybeans sheltered by temporary corn windbreaks. Crop Sci. 13:543-548.

10. Rosenberg, N. J. 1966. Microclimate, air mixing, and phys. iological regulation of transpiration as influenced by wind shelter in an irrigated bean field. Agric. Meteorol. 3:197. 224.

11. Rosenberg, N. J. 1974. Microclimate: The biological environment. Wiley and Sons, New York.

12. Scholander, P. F., H. T. Hammel, E. A. Hemmingsen, and E. D. Bradstreet. 1964. Hydrostatic pressure and osmotic potential in leaves of mangroves and some other plants. Proc. Nat. Acad. Sci. USA. 52:119-125.

13. Shaw, R. H., and D. R. Laing. 1966. Moisture stress and plant response. p. 73-94. In W. H. Peirre, D. Kirkham, J. Pesek, and R. H. Shaw (ed.). Plant environment and efficient water use. Am. Soc. of Agron., Madison, Wis.

14. Stevenson, K. R., and R. H. Shaw. 1974_-Diurnal changes in leaf resistance to water vapor diffusion at different heights in a soybean canopy. Agron. J. 63:17-19.

15. Van Eimern, J., R. Karshon, L. A. Razumova, and C. W. Robertson. 1964. Windbreaks and shelterbelts. Tech. Note No. 59, WMO. No. 147, 70 TP, Secretariat of the World Meteorol. Organization, Geneva, Switzerland. 